\title{
New considerations about Duane's syndrome
} Novas considerações sobre a síndrome de Duane

Carlos Ramos de Souza-Dias ${ }^{1}$

\begin{abstract}
The author presents his arguments to state that the Duane's syndrome type III of the Huber's classification does not exist. He takes the chance of those arguments to show why the medial rectus muscle recession in Duane's syndrome with esotropia cripples the adduction more that it does in esotropias of other origins. He shows also why one must recess also the sound eye's medial rectus in Duane's syndrome with esotropia.
\end{abstract}

Keywords: Duane retraction syndrome/diagnosis; Duane retraction syndrome/ classification; Ophthalmoplegia; Esotropia; Oculomotor muscles/surgery 
$\mathbf{F}$ irst I want to define the subject about which Ishall make some comments. I don't subscribe tothe existence of the Duane's syndrome type III of the Huber's classification ${ }^{(1)}$, but I utilize the electromyographic basis of his work, as well as other electrophysiological and anatomic works, to state that there are only two types of Duane's syndrome, types I and II.

Huber's electromyographic investigations showed that in Duane's syndrome type I the lateral rectus muscle does not receive normal innervation in the attempt of abduction but it contracts abnormally when the eye adducts ${ }^{(1)}$. Anatomic works showed that the abducens nerve is absent and a certain number of nervous fibers abandon the branch of the III nerve destined for the medial rectus and go to innervate the lateral rectus ${ }^{(2-6)}$, confirming the theoretic suspects of Huber ${ }^{(1)}$. Thus, in this kind of Duane's syndrome, the lateral rectus contracts only in the opposite lateroversion, i.e., when the eye adducts, configuring a co-contraction among medial and lateral rectus muscles, and the affected eye retracts in adduction and has no normal abduction.

The amount of fibers that abandon the medial rectus' nerve is variable; if they are scarce, the horizontal co-contraction is very asymmetric, i.e., the medial rectus is much stronger than the lateral rectus and, consequently, the adduction is not significantly impaired; the bridle effect produced by the co-contraction a ${ }^{(7)}$ is feeble, with consequent small retraction in adduction and there are no anomalous vertical deviations ( $u p$ and downshoot). There can be confusion between this case and lateral rectus palsy which, though rarely congenital, it may be so ${ }^{(8)}$ (Figure 1).

If the number of fibers that abandon the medial rectus' nerve toward the lateral rectus is greater, the cocontraction is less asymmetric; there is lesser difference of forces between the medial and the lateral recti in adduction, because the innervation of the medial rectus is reduced and the one of the lateral rectus is increased. The adduction starts to be somewhat impaired, the bridle effect is stronger, with larger retraction, and there can be small anomalous vertical movements ${ }^{(7)}$. In these two situations, there is generally esotropia with tendency to medial rectus contracture (Figure 2).

All these details increase their intensity as the number of fibers that abandon the medial rectus' nerve increases, which leads this muscle to lose force and the lateral rectus to gain force in its abnormal contraction, until arriving to the situation in which their forces equalize themselves (symmetric co-contraction). In this situation there is no adduction or abduction (the abducens
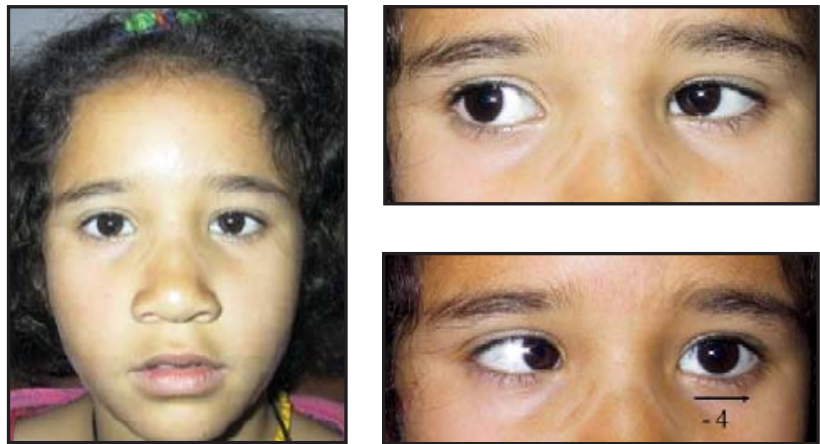

Figure 1: Mild Duane's syndrome type I. Few fibers leave the medial rectus' nerve toward the lateral rectus; very asymmetric cocontraction; absence of normal abduction, presence of normal adduction and no abnormal vertical movements


Figure 2: A little worse Duane's syndrome type I (eso Duane's); A little more fibers leave the medial rectus nerve toward the lateral rectus; Less asymmetric co-contraction; stronger retraction and small upshoot on adduction
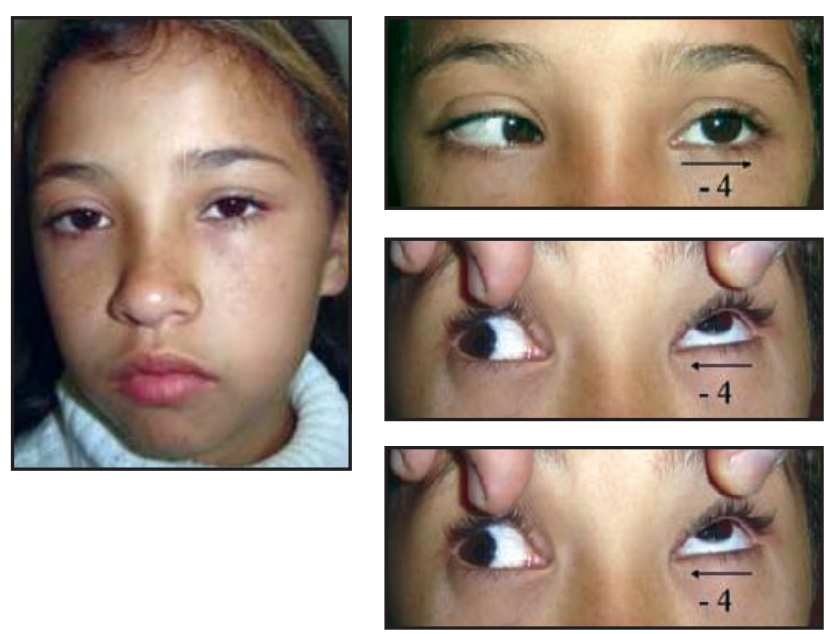

Figure 3: Huge Duane's syndrome type I (Huber's type III). More fibers leave the medial rectus' nerve toward the lateral rectus; Total limitation of active adduction and abduction. Symmetric and strong co-contraction with large up and downshoots 

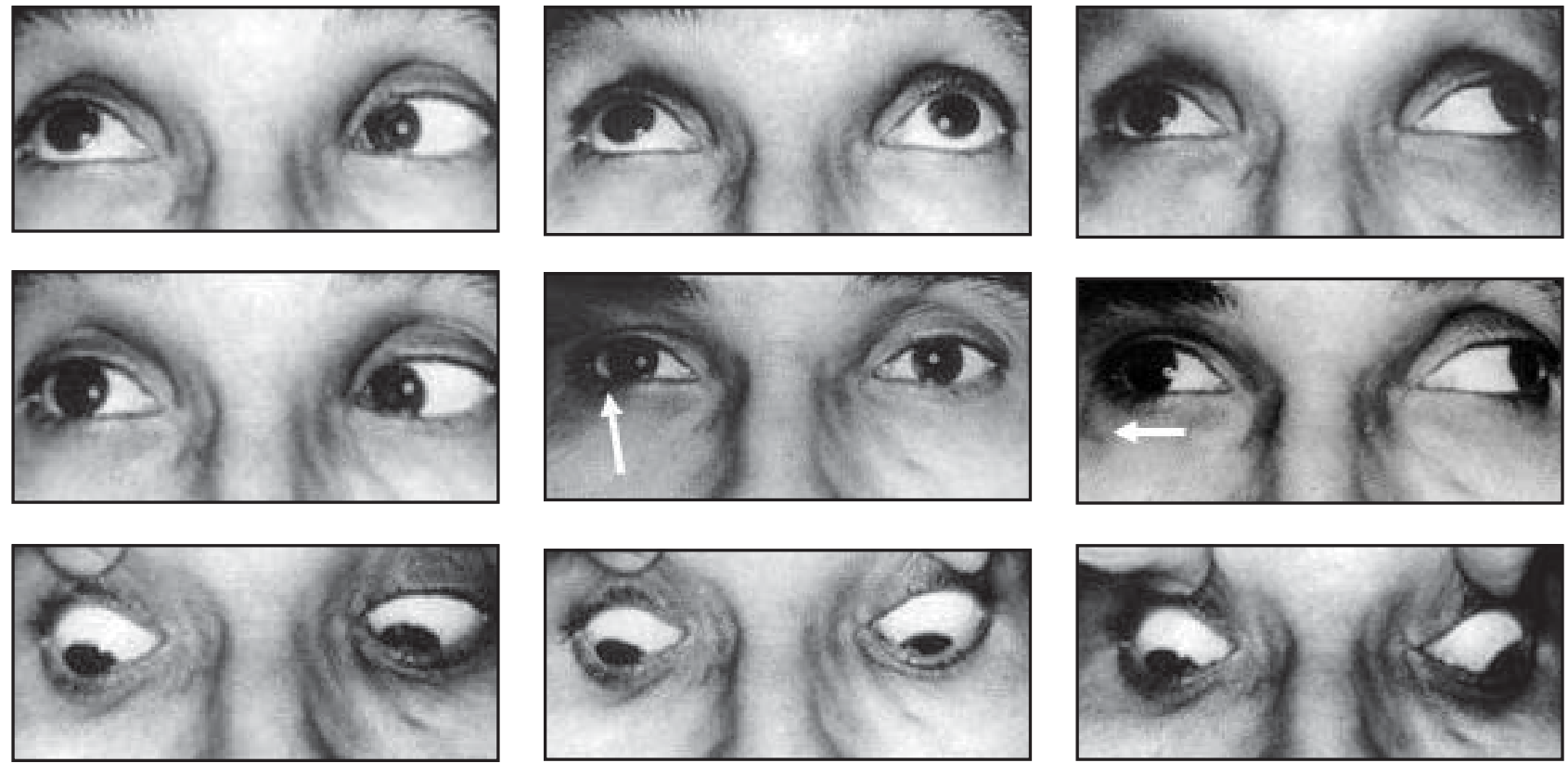

Figure 4: Synergistic abduction (classical synergistic divergence); The right lateral rectus is stronger than the medial rectus. Thus, when the sound left eye abducts, the affected right eye abducts instead of adducting

nerve is absent), the bridle effect of the co-contraction is maximal and consequently the retraction and the anomalous vertical movements are more evident ${ }^{(7)}$.This is the situation that Huber calls Duane's syndrome type III $^{(1)}$ which, in my opinion, is nothing more than a more intense Duane's syndrome type I. It is a simple question of degree. In this situation there is generally exotropia with lateral rectus and sometimes also medial rectus increasing contracture (Figure 3 ).

If the number of fibers that leave the medial rectus' nerve toward the lateral rectus is still greater, one arrives to the situation classically known as synergistic divergence; the lateral rectus becomes stronger than the medial rectus in the co-contraction and, consequently, in the attempt of adduction the affected eye abducts instead of adducting. The asymmetry of the co-contraction is inverted. In this way, when the sound eye abducts, the affected one also abducts. The affected eye's adduction is generally very small (Figure 4).

In 1979, when I saw this kind of clinical picture by first time, I could find only four references about it in the literature, each one with a different mechanical explanation, but I couldn't agree with none of them. I suggested, at the IV Congress of the Latin-American Council of Strabismus (CLADE), Medellín, Colombia ${ }^{(8,9)}$, that the phenomenon was caused by a Duane's syndrome with a medial rectus palsy, which was later confirmed. This palsy is probably caused by the exit of a great number of fibers from the medial rectus' nerve, which remains under-innervated. There is generally a large exotropia with lateral rectus contracture. In this case, contrarily to which occurs with other types of Duane's syndrome, one is authorized, beside the lateral rectus recession, to resect the medial rectus of the affected eye, to act as a leash to help avoiding the recurrence of the exotropia, for it is practically paralyzed. In the case of a huge exotropia, it is indicated to suture the lateral rectus in the orbital periosteum $^{(10)}$.

I consider the term synergistic divergence inadequate, for divergence is a singular binocular phenomenon and, to exist synergism, it is necessary the presence of at least two things; I suggest the more descriptive name synergistic abduction (abduction of the two eyes). Jampolsky names it the splits ${ }^{(11)}$ but he agreed with me when I proposed this new name at the XVII Congress of the CLADE, in 2008, in Buenos Aires (personal communication).

The synergistic abduction can be caused iatrogenically by exaggerated medial rectus recession in Duane's syndrome with esotropia, especially when the anomalous function of the lateral rectus is strong, with consequent weakness of the medial rectus, which confirms my theory of Duane's syndrome as its pathogenesis $^{(9)}$.

All the aforementioned refers to Duane's syndrome type I. One can consider also the existence of Duane's syndrome type II, which fundamental difference from the type I syndrome is that in the type II the lateral 

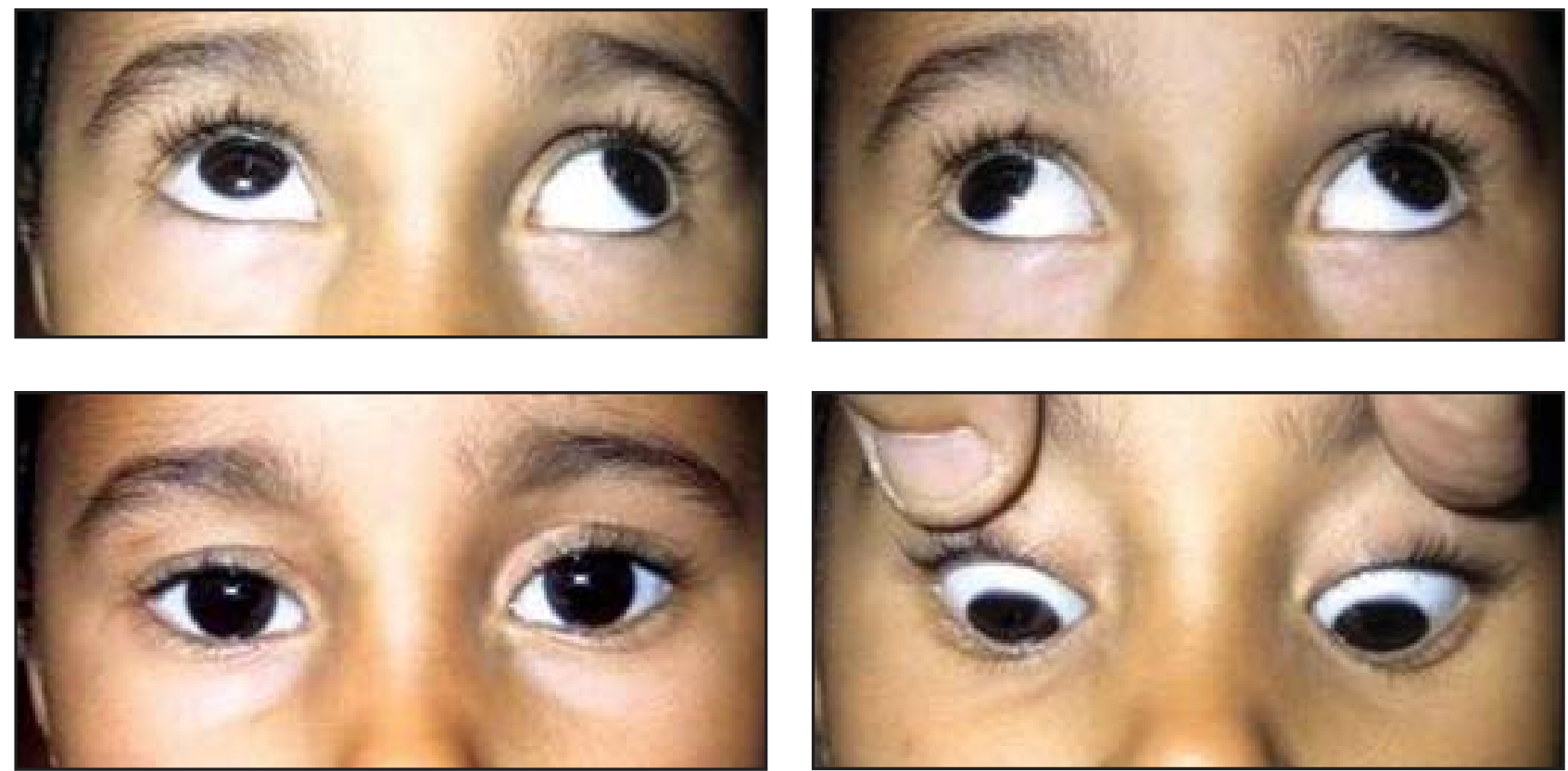

Figure 5: Duane's syndrome with orthotropia in primary position and infraversion and divergence in supraversion; (abnormal abduction of the affected left eye); (Known as Duane IV in Latin America)

rectus receives normal innervation from the abducens nerve, i.e., the eye abducts in the ipsolateroversion. This abduction, however, can be subnormal. The bridle effect of the co-contraction is generally strong and there is strong tendency to lateral rectus contracture. The retraction and the anomalous vertical movements are generally very evident, the adduction is more impaired and there is almost always exotropia ${ }^{(8)}$, which often increases with time because of the development of lateral rectus contracture. This type of Duane's syndrome is less frequent than the type I.

There are other rarer types of Duane's syndrome, as the one in which there is orthotropia in primary position and in infraversion, but a large exotropia in supraversion (Figure 5) due to anomalous innervation of the lateral rectus in this position. In Latin America this kind of Duane's syndrome is known as Duane IV and it was presented by first time by Dr. Cyro Ribeiro, from Cascavel, Brazil. There is also the inverse situation, i.e., cases with orthotropia in primary position and in supraversion and a large exotropia in infraversion due to anomalous innervation of the lateral rectus in this position ${ }^{(12-14)}(\mathrm{Fi}-$ gure 6).

I have seen few cases of a bizarre type of Duane's syndrome in which when the sound eye abducts the affected one descends in the same proportion ${ }^{(8)}$ (Figure 7). In this case, probably there are some nervous fibers primitively destined for the medial rectus that innervates the inferior rectus.

The aforementioned considerations lead to a question: why a medial rectus recession in Duane's syndrome cripples adduction more than in other kinds of esotropia?

In a normal eye, there is a balance of forces in the primary position; when the person intends to adduct, he/ she increases the medial rectus force and reduces the one of the lateral rectus (Sherrington's law) and the eye adducts normally. In a case of lateral rectus paresis, there is an imbalance of horizontal forces in primary position and the eye gets equilibrium in adduction when in rest situation (esotropia); when the patient adducts, he/she increases the medial rectus' force and reduces still more the paretic lateral rectus' force: the eye adducts exaggeratedly. If in this case one performs a medial rectus recession, one re-equilibrates the horizontal forces in primary position (orthotropia). The adduction becomes normal.

In a case of Duane's syndrome with esotropia, there is an imbalance of horizontal forces in the primary position and the affected eye gets balance in adduction (esotropia). When the patient intends to adduct, he/she increases the medial rectus force and, instead of reducing the lateral rectus force (Sherrington's law), it increases (abnormal innervation). If one recesses the medial rectus, one can equilibrate the horizontal forces in primary position but, when the patient tries to adduct, he/she 

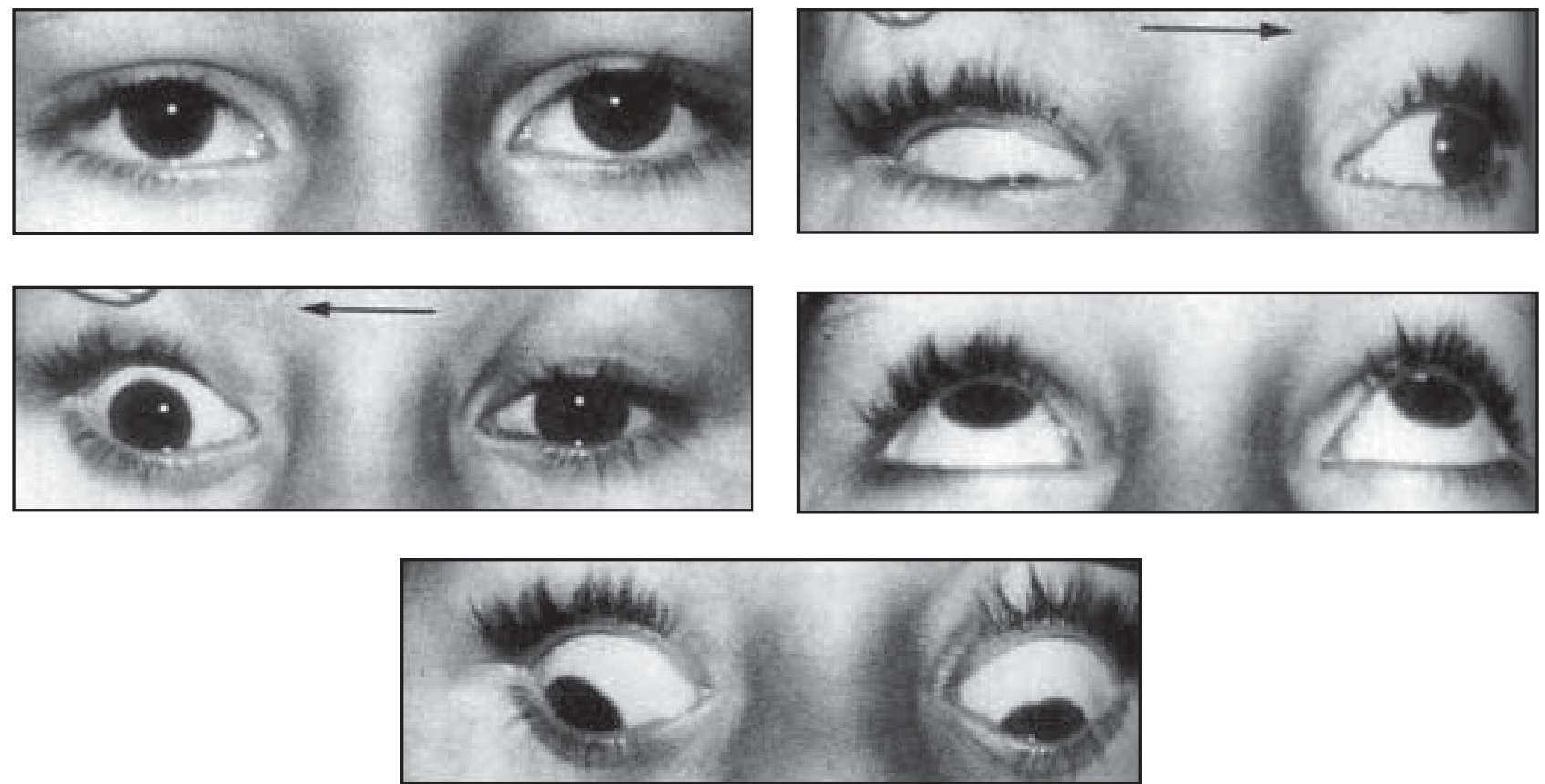

Figure 6: Bilateral Duane's syndrome (severe type I in the right eye and type II in the left eye); There is orthotropia in primary position and supraversion and divergence in infraversion (abnormal abduction of the right eye)

increases the adducting force of the surgically weakened medial rectus and an abducting force is created. The horizontal forces remain equilibrated in primary position, the eye retracts but doesn't move horizontally. This is an obvious exaggeration, but my intention was to show why a medial rectus recession in Duane's syndrome weakens exaggeratedly the adduction.

The weakening effect on the medial rectus in this case depends on the anomalous abducting lateral rectus force in adduction, which is difficult to evaluate clinically. The special forced duction test of RomeroApis ${ }^{(15)}$ may be useful in this case. The adjustable surgery is indicated.

There are some cases in which the esotropia is very large (larger $\tan 30^{\mathrm{D}}$ ); in order to correct entirely the deviation it would be necessary a very large medial rectus recession, which would cripple too much the adduction, causing a horizontal immobility, as cited above. In this case, it is necessary a compromise between the correction of the esotropia and the adduction weakening effect, keeping part of the torticollis but not impairing too much the adduction ${ }^{(8)}$. The recession of the contralateral medial rectus can help reducing the esotropia in this case, as commented below.

Let us analyze why one must recess also the sound eye's medial rectus in cases of unilateral type I Duane's syndrome with esotropia. When one recesses the medial rectus of the affected eye, one tends to balance the hori- zontal forces in primary position with reduction of the deviation angle. As aforementioned, one cannot do a very large recession, necessary to correct a large esotropia; As it is known, one cannot resect the lateral rectus in Duane's syndrome, which would help to align the eye, because it would increase the retraction and the adduction limitation. Recessing the sound eye's medial rectus, one transfers the balance of the passive forces of this eye toward abduction; when the patient wakes up, he/she has to increase the innervation to the medial rectus in order to replace the eye in primary position (the sound eye is generally the dominant one). This innervational increase would be transferred to the affected eye's lateral rectus (Hering's law) but, as the abducens nerve is absent, nothing happens. But this unuseful intended innervation leads to relaxation of this eye's medial rectus (Sherrington's law), which helps to drive the affected eye toward the primary position (orthotropia). Moreover, the medial rectus relaxation helps to minimize its tendency to contracture, which sometimes leads to recurrence of the esotropia in these cases ${ }^{(8)}$. My usual procedure is to recess the sound eye's medial rectus 6 to $7 \mathrm{~mm}$, especially in large esotropias.

An important observation is that it is dangerous to recess the medial recti in cases of bilateral Duane's syndrome when there is normal fusion in some compensatory head position, if there is the more tenuous normal action of the lateral recti. This may cause a difficult to eliminate diplopia because, no matter what is 

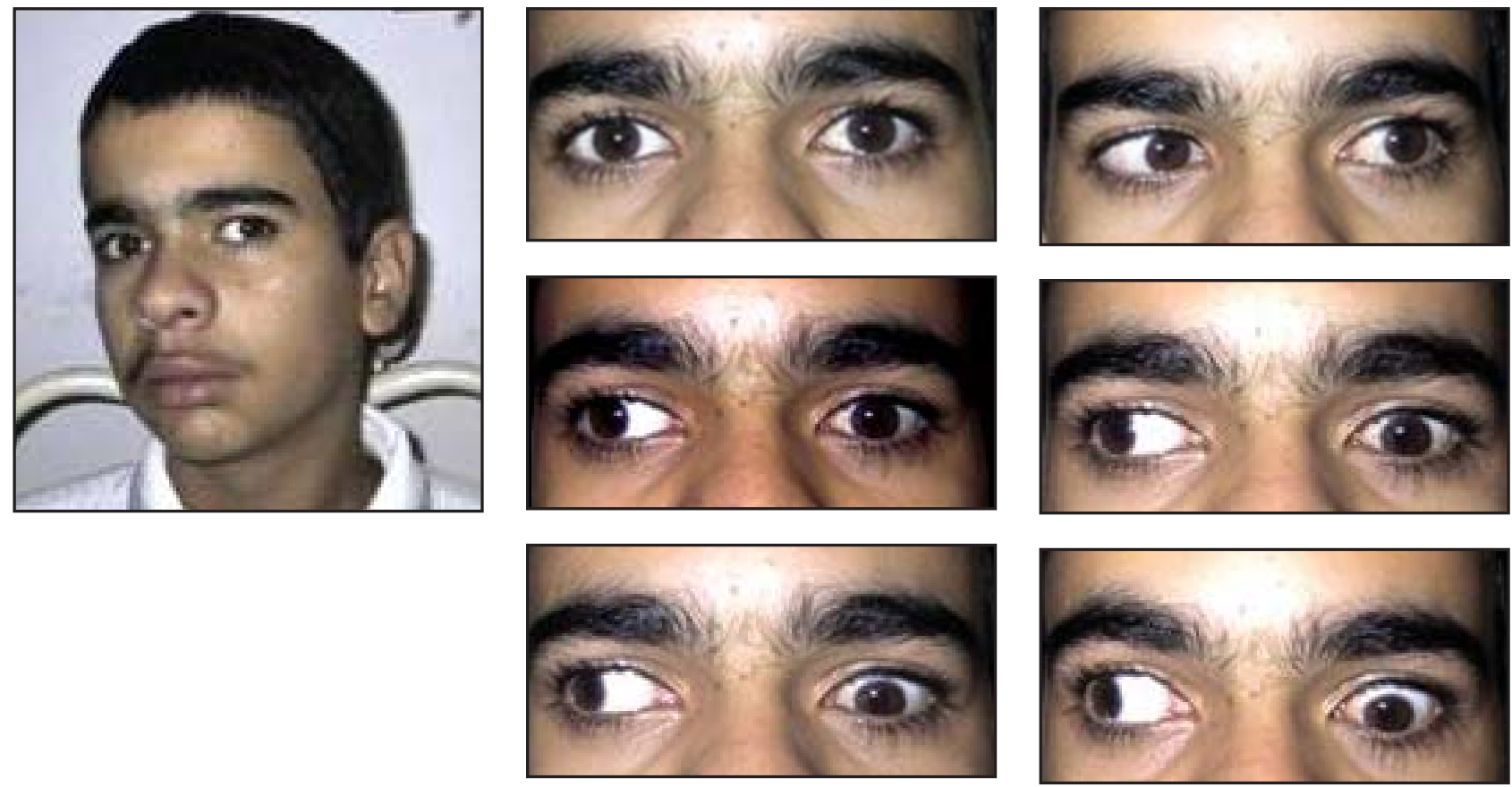

Figure 7: Bizarre Duane's syndrome; The affected left eye is balanced in abduction, which requires torticollis in order to gain normal binocular vision (exotropia when fixing with the right eye in primary position); As the sound right eye abducts, the left eye, instead of adducting, descends proportionally to the degree of abduction. Probably the left inferior rectus receives the innervations that would be directed to the medial rectus

the dominant eye, an increase of adducting innervation may lead the fellow eye to abduct (Hering's law), causing an exotropia. I have had this terrible experience.

Lastly, I want to make another important observation. Elsas ${ }^{(16)}$ called attention to a possibility, which he coined "occult Duane's syndrome". There are some cases of bilateral Duane's syndrome with large angle esotropia with bilateral limitation of abduction, simulating a Ciancia's syndrome. The differential diagnose between these two situations is difficult in small babies. At surgery, the surgeon feels a strong passive abduction limitation (medial rectus contracture). The medial rectus recession may offer an acceptable result in the correction of the deviation, but it weakens strongly the adduction, which can even be eliminated. Postoperatively the surgeon perceives that it is a bilateral Duane's syndrome. In this case, there is a tendency to exotropia with time. This situation can be even worse if the surgeon performed also a lateral rectus resection.

\section{ResUmo}

O autor expõe argumentos para afirmar que não existe a síndrome de Duane tipo III da classificação de Huber. Aproveitando esses argumentos, mostra por que o retrocesso do músculo reto medial em síndrome de Duane com esotropia prejudica a adução mais do que o faz em esotropias de outras origens. Mostra, também, por que se deve retroceder também o músculo reto medial do olho não afetado em síndrome de Duane com esotropia.

Descritores: Síndrome da retração ocular/diagnóstico; Síndrome da retração ocular/classificação; Oftalmoplegia; Esotropia; Músculos oculomotores/cirurgia

\section{RefERENCES}

1. Huber A. Duane's retraction syndrome: considerations on pathogenesis and aetiology of the different forms of Duane's retraction syndrome. In: Strabismus'69. London: Henry Kimpton; 1970. p. 36-43.

2. Hoyt WF, Nachtigäller H. Anomalies of ocular motor nerves. Neuroanatomic correlates of paradoxical innervation in Duane's syndrome and related congenital ocular motor disorders. Am J Ophthalmol. 1965;60(3):443-8.

3. Phillips WH, Dirion JK, Graves GO. Congenital bilateral palsy of abducens. Arch Ophthalmol. 1932;8:355-64.

4. Matteucci P. I difeti congeniti di abduzione con particolare riguardo alla patogenesi. Rass Ital Oftalmol. 1946;15:345.

5. Hotchkiss MG, Miller NR, Clark AW, Green WR. Bilateral Duane's retraction syndrome. A clinical-pathologic case report. Arch Ophthalmol. 1980;98(5):870-4.

6. Miller JM, Demer JL, Rosenbaum AL. Two mechanisms of up-shoot and down-shoot in Duane's syndrome revealed by a new magnetic resonance imaging (MRI) technique. In: Campos EC. Editor. Strabismus and ocular motility disorders. Proceedings of the Sixth Meeting of the I.S.A.; 1990. p. 229 
7. Souza-Dias C.Additional consequences of muscle co-contraction in Duane's syndrome. In: Smith-Kettlewell Symposium on Basic Sciences and Strabismus. Annex to Congreso del Consejo Latinoamericano de Estrabismo (CLADE). São Paulo: Oficinas das Edições Loyola; 1976. p.93.

8. Prieto-Díaz J, Souza-Dias C. Estrabismo. 5a ed. Buenos Aires: Ediciones Científicas Argentinas;2005. p. 427-55.

9. Souza-Dias C. Considerações etiopatogênicas sobre a assim chamada "divergência sinérgica". Rev Latinoam Estrabismo.1979;3(1):42. [Anais do VI Congresso do CLADE; 1979].

10. Morad Y, Kowal L \& Scott AB: Lateral rectus muscle disinsertion and reattachment to the lateral orbital wall. $\mathrm{Br} \mathrm{J}$ Ophthalmol. 2005;89:983-5

11. Jampolsky A. Duanes syndrome. In: Rosembaum AL, SantiagoAP, editors. Clinical strabismus management: principles and techniques. Philadelphia: WB Saunders; 1999. p. 325-46.

12. Mohan K, Sharma A, Pandav SS. Differences in epidemiological and clinical characteristics between various types of Duane retraction syndrome in 331 patients. J AAPOS. 2008;12(6):576-80.
13. Papst W \&Stein HJ. [Zur chirurgischen Behandlung der paradoxen innervation]. Ber Zusammenkunft Dtsch Ophthalmol Ges. 1970; 70: 345. German.

14. Sato S. Electromyographic studies on Duane's retraction syndrome. Quantitative changes of motion currents of extraocular muscles in ocular movements. Acta Soc Ophthalmol Jpn. 1959;63:2028-30.

15. Romero-Apis D. Estrabismo. México: Editorial Auroch; 2000. p. 242

16. Elsas FJ. Occult Duane syndrome: co-contraction revealed following strabismus surgery. J Pediatr Ophthalmol Strabismus. $1991 ; 28(6): 328-32$.

\section{ENDEREÇO PARA CORRESPONDÊNCIA \\ Carlos R. Souza Dias \\ Rua Cincinato Braga, $\mathrm{n}^{\circ} 59$ - conj. 5 B2 \\ CEP 01333-011 - São Paulo - SP \\ Fax: (11) 5575-2669 \\ E-mail: csdias@uol.com.br}

